\title{
Pendidikan agama inklusif sebagai fondasi moderasi beragama: Strategi merawat keberagaman di Indonesia
}

\author{
Yance Z. Rumahuru ${ }^{*}$, Johana S.Talupun ${ }^{2}$ \\ ${ }^{1,2}$ Institut Agama Kristen Negeri Ambon \\ *Correspondence: yancerumahuru@gmail.com
}

\begin{tabular}{|c|c|}
\hline $\begin{array}{l}\text { (1) https://orcid.org/0000- } \\
\text { 0002-7892-1606 } \\
\text { Keywords: } \\
\text { religious moderation; } \\
\text { religious education; } \\
\text { inclusive religious } \\
\text { education; } \\
\text { Christian education; } \\
\text { radicalism; } \\
\text { moderasi beragama; } \\
\text { pendidikan agama; } \\
\text { pendidikan agama inklusif; } \\
\text { pendidikan agama Kristen; } \\
\text { radikalisme }\end{array}$ & $\begin{array}{l}\text { Abstract: The phenomenon of radicalism and religious extremism has streng- } \\
\text { thened in Indonesia in the last decade, even though Indonesia is known as a } \\
\text { friendly and tolerant country. The religious education provided from ele- } \\
\text { mentary school to university has not built an inclusive spiritual perspective and } \\
\text { attitude. It is assumed that religious teaching, including Christian Religious } \\
\text { Education, is still teaching a narrow doctrine. Many do not see diversity as an } \\
\text { important context in religious learning. This article aims to promote inclusive } \\
\text { religious education as the foundation of religious moderation in Indonesia. } \\
\text { This study uses a qualitative approach, with the method of analyzing the } \\
\text { results of previous studies related to the policy and implementation of } \\
\text { religious education in Indonesia, as well as conducting observations and } \\
\text { interviews regarding the practice of religious education in schools on a macro } \\
\text { basis, and making comparisons with the results of available research. This } \\
\text { study finds that a paradigm shift in religious education is needed, both at the } \\
\text { level of policymakers and education implementers. This study offers an } \\
\text { inclusive spiritual education paradigm that changes the perspective and } \\
\text { attitude of exclusive religion because it prioritizes mutual trust and respect for } \\
\text { human equality. }\end{array}$ \\
\hline $\begin{array}{l}\text { Copyright: } \bigcirc 2021 \text {, Authors. } \\
\text { License: } \\
\text { (c) (1) }\end{array}$ & $\begin{array}{l}\text { Abstrak: Fenomena radikalisme dan ekstrimisme agama semakin menguat di } \\
\text { Indonesia pada dekade terakhir ini, padahal Indonesia dikenal sebagai negara } \\
\text { yang ramah dan toleran. Bahkan, pendidikan agama yang diberikan sejak } \\
\text { tingkat Sekolah Dasar hingga perguruan tinggi rupanya belum mampu mem- } \\
\text { bangun perspektif dan sikap beragama yang inklusif. Diasumsiskan bahwa } \\
\text { pendidikan agama, termasuk Pendidikan Agama Kristen, yang diajarkan masih } \\
\text { berorientasi pada pengajaran doktrin yang sempit, sehingga belum banyak } \\
\text { melihat keberagaman sebagai salah satu konteks penting dalam proses pem- } \\
\text { belajaran agama. Artikel ini bertujuan mempromosikan pendidikan agama } \\
\text { inklusif sebagai fondasi moderasi beragama di Indonesia. Kajian ini meng- } \\
\text { gunakan pendekatan kualitatif, dengan metode analisis terhadap hasil kajian } \\
\text { sebelumnya terkait kebijakan dan implementasi pendidikan agama di Indone- } \\
\text { sia, serta mengadakan pengamatan dan wawancara terkait praktik pendidikan } \\
\text { agama di sekolah secara makro, dan melakukan perbandingan dengan hasil- } \\
\text { hasil penelitian yang tersedia. Studi ini menemukan bahwa diperlukan peruba- } \\
\text { han paradigma pendidikan agama, baik pada level pengambil kebijakan mau- } \\
\text { pun pelaksana pendidikan. Kajian ini menawarkan paradigma pendidikan aga- } \\
\text { ma inklusif, yang dipandang dapat mengubah perspektif dan sikap beragama } \\
\text { eksklusif, karena mengutamakan sikap saling percaya dan penghargaan ter- } \\
\text { hadap kesederajatan umat manusia. }\end{array}$ \\
\hline
\end{tabular}




\section{Pendahuluan}

Pendidikan agama sebagai pembentuk moral dan karakter, disadari atau tidak, berpotensi memroduksi pemikiran dan sikap eksklusivitas agama, yang menjadi titik pijak fundamentalisme, dan berkembang menjadi radikalisme dan ektrimisme agama. Implementasi pendidikan agama di sekolah (masyarakat) belum sepenuhnya membantu pembentukan nilai-nilai luhur, keimanan dan ketagwaan kepada Tuhan yang Maha Esa bagi setiap siswa atau nara didik sebagaimana diamanatkan undang-undang, dan hakikat pendidikan untuk memanusiakan manusia. Pendidikan agama, sama seperti pendidikan umumnya diharapkan membentuk kecakapan intelektual dan emosional yang menghargai kesederajatan manusia. Apabila pendidikan agama dapat diimplementasikan membangun aspek intelektual, emosional, spiritual dan penghargaan terhadap kesederajatan manusia maka diharapkan pendidikan agama menjadi jalan tengah terhadap persoalan eksklusivisme dan panatisme sempit agama-agama dengan segala akibatnya. Penulis menawarkan pendidikan agama inklusif sebagai media moderasi beragama dalam hal merawat keberagaman di Indonesia.

Dalam konteks Indonesia, mengacu pada Undang-Undang Nomor 20 tahun 2003, tentang Sistem Pendidikan Nasional, salah satu aksentuasinya adalah kekuatan spiritual keagamaan dan akhlak mulia maka pendidikan agama dan pendidikan keagamaan memiliki posisi strategis dalam rangka membangun karakter bangsa. Pendidikan agama, termasuk penddiian agama Kristen perlu diformulasi dalam "perspektif baru", mengacu pada konteks kemajemukan dan menjangkau komunitas lebih luas. Dalam hal ini pendidikan agama sudah sepatutnya dijadikan media efektif mengembangkan pemikiran inklusif dan menjadi filter terhadap paham keagamaan dan panatisme sempit agama yang memungkinkan berkambangnya radikalisme, ekstrimisme dan terorisme. Fenomena pemaksaan mengikuti tradisi agama tertentu oleh pihak sekolah kepada siswanya, serta fenomena konflik antarsiswa beda agama dan etnik di sekolah pada beberapa tempat di Indonesia akhir-akhir ini, secara nyata menunjukkan bahwa pendidikan agama belum sepenuhnya membantu membangun penerimaan terhadap keberagaman dan saling menghargai antarsesama, apalagi bersolidaritas dan saling menolong lintas komunitas. Apa yang terjadi di sekolah sebetulnya menggambarkan realitas bermasayarakat di Indonesia secara luas. Oleh karena itu, perlu dipikirkan strategi pengembangan pendidikan agama yang membantu memroduksi pemahaman dan sikap inklusif dan solider terhadap kehidupan yang melampauwi sekatsekat agama dan etnik.

Literatur tentang implementasi pendidikan agama di Indonesia menunjukkan dua kecenderungan. Pertama, kurikulum dan materi ajar yang diberi kepada nara didik lebih menekankan pada pengajaran doktrin agama secara sempit atau dapat disebut sebagai pendidikan agama yang eksklusif. ${ }^{1}$ Pendidikan agama yang ekslusif secara nyata telah menjadi lahan subur tumbah dan berkembangnya radikalisme, ekstrimisme, dan terorisme. ${ }^{2}$ Kedua, proses pendidikan dengan modifikasi kurikulum dan pengajaran agama yang mengalami perluasan makna dengan menggunakan perspektif multikultur dan pendidikan perdamaian, atau dapat disebut pendidikan agama yang inklusif. Pendidikan agama berbasis multikultur dan pendidikan perdamaian memungkinkan terjadi penerimaan terhadap yang lain karena mengacu pada penghargaan terhadap keragaman dan upaya bina damai, suatu potensi yang sesungguhnya terdapat pada ajaran setiap agama. $^{3}$

\footnotetext{
${ }^{1}$ M. Saerozi, Politik Pendidikan Agama Dalam Era Pluralisme (Yogyakarta: Tiara Wacana, 2004); Laode Arham Listia and Lian Gogali, "Problematika Pendidikan Agama Di Sekolah: Hasil Penelitian Tentang Pendidikan Agama Di Kota Jogjakarta 2004-2006," Yogyakarta: Interfidei/Dian (2007).

${ }^{2}$ Iqbal M Ahnaf, Praktik Pengelolaan Keragaman Di Indonesia: Jalan-Jalan Alternatif Membangun Inklusi Sosial (Yogyakarta: CRCS UGM, 2018); Ihsan Ali-Fauzi, Buku Panduan Melawan Hasutan Kebencian (Jakarta: PUSAD Yayasan Paramadina, 2019).

${ }^{3}$ James A Banks, "Approaches to Multicultural Curriculum Reform," in Multicultural Education: Issues and Perspectives, ed. James A Banks and Cherry A.McGee Banks (New York: Jhon Willey \& Sons.Inc, 2010).
} 
Tulisan ini melengkapi kajian sebelum dengan meletakkan pentingnya pendidikan agama inklusif sebagai upaya mempromosikan dan menjadikan pendidikan agama sebagai fondasi moderasi beragama di Indonesia. Pendidikan agama inklusif memberi penekanan pada penerimaan terhadap eksistensi kelompok atau komunitas lain di luar dirinya, sehingga terbangun sikap saling peduli dan berbelarasa, adanya saling percaya (trust), dan tentu saling menjaga di antara sesama pemeluk agama. ${ }^{4}$ Pendidikan agama inklusif mengakar pada konteks kemajemukan masyarakat maupun konteks pembelajaran agama itu sendiri yang mesti didekati dari beragam perspektif sehingga tidak menjadikan pembelajran agama sempit dan eksklusif. Apalagi, pada hakikatnya, setiap pembelajaran agama mengedepankan nilai-nilai kasih, perdamaian, dan keadilan.

Pendidikan agama sebagai fondasi moderasi beragama diharapkan memberi solusi agar setiap nara didik berpikir dan bertindak moderat. Moderat sebagaimana dimaksud menunjuk pada sikap sewajarnya, dan tidak ekstrim, sehingga memungkinkan setiap orang dapat berinteraksi dan berelasi dalam perbedaan. Pendidikan agama seperti ini dengan sendirinya menjadi jalan merawat kehidupan. Tulisan ini dibangun dengan asumsi bahwa pendidikan agama inklusif potensial menumbuhkan nilai-nilai positif bagi setiap siswa dalam rangka membangun kesadaran keberagaman sebagai sesuatu yang terberi sekaligus fakta sosial yang tidak dapat terelakan. Keberagaman sebagai fakta sosial maupun anugerah yang terberi patut disykuri dan dijadikan konteks aktual pembelajaran agama dalam setiap komunitas atau kelompok masyarakat. ${ }^{5}$ Dua pertanyaan utama kajian ini adalah: Bagaimana seharusnya pendidikan agama dilaksanakan mewujudkan tatanan hidup masyarakat yang menerima secara kritis realitas keberagaman dan membangun kehidupan yang bersolider satu dengan lainnya; dan, bagaimana pula strategi dalam pendidikan agama untuk mewujudkan harmoni sosial dalam keragaman masyarakat di Indonesia?

Pada level kebijakan, secara ideal, tampak bahwa negara memberikan legitimasi pendidikan agama untuk meningkatkan keimanan dan ketakwaan subjek didik pada setiap agama ${ }^{6}$, tetapi praksis pendidikan agama di masyarakat atau sekolah-sekolah belum sepenuhnya mengimplementasikan pendidikan agama yang memungkinkan penerimaan terhadap keberagaman secara lebih baik. Padahal hakikatnya, pendidkan agama memberi penanaman nilai dan etika untuk menghargai sesama dalam keberadaannya. Dalam perspektif pendidikan kritis dapat disebut bahwa sudah sepatutnya pendidikan (agama) mengambil peranan dalam memroduksi dan menciptakan kehidupan publik, bukan sekadar beradaptasi dengan realitas sosial. Dalam kaitan ini, Freire menawarkan pendidikan sebagai "bahasa kritik", yang menghubungkan pendidikan dengan kekuasaan dan politik. Di sini pendidikan merupakan ajang pertarungan berbagai ideologi yang membentuk realitas sosial. Disadari atau tidak, pendidikan, termasuk pendidikan agama sering menjadi ajang perubutan dan pertarungan ideologi. Selain bahasa kritik (language of critique) Freire juga manawarkan bahasa harapan (language of hope), yaitu sebuah motor penggerak, sekaligus sebuah kebutuhan mendasar yang sangat penting dalam pendidikan pembebasan. ${ }^{7}$

Pemikiran sebagaimana dikemukakan menegaskan perspektif filsafat pendidikan, yang melihat pendidikan sebagai analisis kritis dan komprehensif tentang cara pendidikan, dilaksanakan atau diselenggarakan dalam mewujudkan tatanan masyarakat yang berkeadaban. ${ }^{8}$ Pendidikan memiliki tujuan secara khusus agar setiap indvidu diarahkan untuk membangun suatu pandangan yang positif tentang kecerdasan, daya kreatif, dan keluhuran budi perkerti. Dalam perspektif

\footnotetext{
${ }^{4}$ Yance Z. Rumahuru, "Mengembangkan Pendidikan Agama Inklusif Sebagai Solusi Pengelolaan Keragaman Di Indonesia," Jurnal Teruna Bhakti 1, no. 1 (2019): 59-68.

${ }^{5}$ Ibid.; Y Z Rumahuru, "Mengembangkan Dialog Untuk Penguatan Misi Agama Yang Transformatif," KENOSIS: Jurnal Kajian Teologi 2, no. 1 (2016): 23-35; Y Z Rumahuru, "Keragaman Agama Sebagai Basis Pembelajaran PAK," MARA CHRISTY 5, no. 2 (2014).

${ }^{6}$ Saerozi, Politik Pendidikan Agama Dalam Era Pluralisme.

${ }^{7}$ Paulo Freire, Politics and Education (California $\backslash$ : UCLA Latin American Center Publications, 1998); Paulo Freire and Anna Maria Araujo, Pedagogy of Hope: Reliving Pedagogy of the Oppressed (New York: Continuum, 1994).

${ }^{8}$ Mudyahardjo, Filsafat Pendidikan (Bandung: Remaja Rosda Karya, 2002), 5.
} 
ini berharap dari pendidikan yang ditawarkan, setiap individu memiliki kompetensi individual yang tinggi dalam menumbuhkembangkan nilai-nilai positif dari tujuan khusus pendidikan. ${ }^{9}$ Kecerdasan dan kearifan bersumber dari daya kritis dan kesadaran individu atas nilai diri dan sosial, sehingga tumbuh kepedulian pada sesama. Kepedulian sosial atau solidaritas sosial yang tumbuh akibat proses pendidikan yang kritis sekaligus menjadi modal penting dalam mengelolah keragaman. Pendidikan agama memiliki posisi penting dan stretegis memnjadi modal utama dalam mengelolah keragaman dan membangun sikap penerimaan terhadap kelompok lain, bukan sebaliknya membangun panatisme sempit dan eksklusif.

\section{MetOde}

Penelitian ini merupakan jenis penelitian deskriptif kualitatif, yang memanfaatkan data dari kajian leteratur, dan melihat aplikasinya dalam proses pendidikan melalui pengamatan dan wawancara terhadap proses pelaksanaan pendidikan agama, baik di sekolah maupun di lingkungan masyarakat. Data yang diperlukan untuk kajian ini berupa kebijakan terkait pendidikan agama, implementasi pendidikan agama, dampak penerapan kebijkan dan proses pendidikan agama yang dikaitkan pula dengan pengelolaan keragaman dan moderasi beragama yang sedang terjadi di Indonesia saat ini.

Tahapan kajian ini adalah sebagai berikut Pengamatan terhadap kebijakan dan implementasi pendidikan; Penelusuran literatur terkait kebijakan dan implemnetasi pendidikan agama di Indonesia; Diskusi dan wawancara dengan beberapa pengajar agama di sekolah; analisis hasil kajian literatur dan kajian lapangan. Proses analisis data dilakukan dengan cara melihat temuan penelitian baik dari data sekunder maupun primer, menarik hubungan-hubungan antara satu dengan lainnya, dan dikaitkan pula dengan konteks sosial masyarakat di Indonesia saat ini. Data yang telah dianalisis disajikan dalam bentuk deskripsi seperti nyata pada tulisan ini.

\section{Pembahasan}

\section{Potret Pendidikan Agama di Indonesia}

Pada bagian ini dikedepankan temuan dari hasil kajian literatur maupun kajian lapangan terhadap fenomena penyelanggaraan pendidikan agama di kalangan masyarakat Indonesia kontemporer saat ini. Pengamatan terhadap implementasi pendidikan agama di Indonesia menunjukkan bahwa terdapat penyelanggaraan pendidikan agama dengan dinamika berbeda pada setiap sekolah dan daerah. Selain itu, kesalahan dalam kebijkan, interpretasi dan imlpmemntasi pendidikan agama berpotensi memproduksi kekerasan dalam masyarakat.

Sebelum melihat seperti apa potret dinamika implementasi pendidikan agama dalam konteks masyarakat Indonesia yang beragam, perlu dikedepankan hasil kajian yang menjelaskan peta permasalahan keragaman di Indonesia. Baqir menjelaskan bahwa terdapat beberapa pemetaan isu keragaman di Indonesia. ${ }^{10}$ Pertama, isu terkait kebijakan publik. Kebijakan publik dapat dilihat pada level nasional dan level daerah. Kebijakan publik sebagaimana dimaksud memengaruhi kebijakan nasional secara tidak langsung (misalnya perdebatan menyangkut beberapa Undang-Undang (UU) yang memolarisasi kelompok-kelompok keagamaan seperti UU Sisdiknas, UU Anti-pornografi, Peraturan Bersama Menteri Dalam Negeri dan Menteri Agama yang menyangkut pendirian rumah ibadah, SKB tentang Jemaat Ahmadiyah Indonesia), maupun yang lebih menyangkut Muslim (seperti UU Zakat, RUU Jaminan Produk Halal). Kedua, terorisme atas nama agama. Pemboman yang dilakukan di beberapa tempat atas nama agama, misalnya pemboman Hotel JW Marriot di Jakarta tahun 2003, Kedubes Australia, Jakarta pada tahun 2014, Jimbaran dan Kuta, Bali di tahun 2005. Ketiga, konflik komunal antar-komunitas beragama

\footnotetext{
${ }^{9}$ Bdk. Soebaedi, Pendidikan Berbasis Masyarakat: Upaya Menawarkan Solusi Terhadap Berbagai Problem Sosial (Ygyakarta: Puataka Pelajar, 2006); Nandika Dodi, Pendidikan Di Tengah Gelombang Perubahan (Jakarta: LP3ES, 2007).

${ }^{10}$ Z A. Baqir, Mengelola Keragaman Dan Kebebasan Beragama Di Indonesia: Sejarah, Teori Dan Advokasi (Yogyakarta: Sekolah Pascasarjana UGM CRCS, 2014).
} 
meledak. Yang paling menarik perhatian tentunya konflik di Ambon, Maluku dan Poso, Sulawesi Tengah. Keempat, ada dua isu utama sebagai sumber konflik antar kelompok-kelompok agama yang makin sering sejak tahun 2008, yaitu terkait dengan tuduhan atas penodaan agama dan kesulitan membangun rumah ibadah.

Pemetaan terhadap isu dan persoalan kemajemukan di Indonesia seperti disebut merupakan akumulasi dari hasil pendidikan agama yang eksklusif di masyarakat, yang mengabaikan eksistensi kelompok lain di luar dirinya. Kecenderungan fokus pada diri sendiri berdamapak pada penerimaan terhadap kemajemukan dan bersikap inklusif. Jika diamati, pendidikan agama yang memberi perhatian pada doktrin eksklusif membentuk fanatisme sempit dan memproduksi kelompok-kelompok agama yang memiliki sikap-sikap kebencian (hatred), kemarahan (anger), tidak toleran (intolerance), dan tindakan diskriminatif (discrimination). Sikap-sikap ini berpotensi menimbulkan konflik dan kekerasan di kalangan umat beragama. ${ }^{11}$

Penelitian interfidei tentang problematika pendidikan agama di sekolah dengan mengambil setting tempat kota Yogyakarta 2004-2006, menemukan bahwa: Pada level politik pendidikan yang berfokus pada kebijakan-kebijakan negara terkait dengan pendidikan agama di sekolah umum ditemukan bahwa terdapat dampak yang cukup jelas dari ketegangan politik berkaitan dengan kesepakatan tentang ideologi negara. Tampak bahwa terdapat kelompok-kelompok agama tertentu masih kesulitan menerima gagasan tentang pemisahan urusan agama dan negara. Bagi kelompok-kelompok ini, agama dihayati sebagai pusat tata nilai dan sumber hukum, termasuk dalam kehidupan bernegara dan bermasyarakat. Sementara, kelompok-kelompok lain sudah terbiasa dengan gagasan pemisahan urusan negara dan agama; Pada level sistem pendidikan, semua persoalan yang ada dalam sistem pendidikan di Indonesia ditemukan juga dalam pelaksanaan pendidikan agama di sekolah; Pada level realitas, masyarakat dan siswa sering kali tidak seperti yang dibayangkan oleh para pemegang kebijakan. Banyak kelompok yang mementingkan harmoni dalam hidup dan meletakkan agama sebagai urusan pribadi, bukan urusan yang harus dibawa ke ranah publik. Di kalangan siswa, sikap santai menghadapi perbedaan agama mudah ditemukan, tetapi oleh pembiasaan yang ditempuh melalui pemisahan siswa pada jam pelajaran agama menanamkan kesadaran dan membentuk cara berpikir mereka bahwa agama sebagai sesuatu yang memisahkan manusia; Pada level institusi pendidikan ditemukan adanya upaya-upaya yang dilakukan oleh kelompok masyarakat melalui lembaga-lembaga pendidikan swasta, mengambil sikap kritis terhadap sistem pendidikan nasional dan khusunya pendidikan agama yang memilih untuk membuat dan mencoba mempraktikkan model pendidikan alternatif. ${ }^{12}$

Studi lain terkiat implementasi pendidikan agama dilakukan oleh Muh. Saerozi yang mengkaji tentang politik pendidikan agama dalam era pluralisme di Indonesia ${ }^{13}$, menemukan bahwa kebijakan negara tentang pola pendidikan agama dilakukan dalam dua pola, yakni: pola konvensional, yaitu negara memberikan legitimasi pendidikan agama untuk meningkatkan keimanan dan ketakwaan subjek didik pada setiap agama; pola non-konvensional, yaitu negara memberikan legitimasi, memperkenalkan berbagai agama di sekolah untuk menyadari adanya berbagai kepercayaan yang diyakini oleh kelompok-kelompok dalam masyarakat. Unsur konvensional dalam kebijakan pendidikan di Indonesia tampak dalam beberapa aspek: Pertama, pendekatan pendidikan agama yang teologis, tetapi terkontrol dengan pendekatan lain yang bekerja kontekstual. Kedua, pendidikan yang diisyaratkan beriman dan bertakwa kepada Tuhan Yang Maha Esa. Ketiga, praktik ibadah dan acara-acara keagamaan yang dilakukan di sekolah negeri. Keempat, pendanaan pendidikan yang dialokasikan bukan hanya untuk lembaga pendidikan negeri bersifat umum, tetapi juga keagamaan, dan swasta berciri khusus agama.

11 Ahnaf, Praktik Pengelolaan Keragaman Di Indonesia: Jalan-Jalan Alternatif Membangun Inklusi Sosial; Ali-Fauzi, Buku Panduan Melawan Hasutan Kebencian.

12 Listia and Gogali, "Problematika Pendidikan Agama Di Sekolah: Hasil Penelitian Tentang Pendidikan Agama Di Kota Jogjakarta 2004-2006."

${ }^{13}$ Saerozi, Politik Pendidikan Agama Dalam Era Pluralisme. 
Mengacu pada studi literature terkait implementasi pendidikan agama di Indonesia, nyata bahwa masih diperlukan kebijakan terhadap pendidikan agama yang mengharuskan perubahan paradigma dan dapat diterjemahkan pada kurikulum dan materi ajar pendidikan agama di sekolah. Pendidikan agama yang diharapkan adalah pendidikan agama yang tidak lagi menekankan pada penguatan doktrin sendiri secara sempit karena hal ini sudah menjadi tanggungjawab setiap lembaga agama dalam mengajari doktrin sendiri. Di sekolah, diperlukan pengajaran agama dengan muatan materi mulai dari penguatan karakter dan budipekerti individu maupun kelompok peserta didik, penguatan moral dan etika, hingga pengembangan nilai-nilai kemanusiaan dan tanggungjawab bersama menjaga dan memelihara bumi sebagai rumah bersama semua ciptaan. Hal ini tentu disesuaikan pada setiap level dan jenjang pendidikan, sehingga setiap siswa sejak sekolah dasar hingga menengah atas diharapkan mengalami pembentukan karakter dengan nilai-nilai yang memungkinkan bagi pengembangan suatu masyarakat yang terbuka dengan karakter dan integritas yang kuat. Hal ini sangat diperlukan untuk merawat dan mengelola keragaman bangsa; membangun daya sang bangsa.

Hasil diskusi dengan guru pendidikan agama Kristen (PAK) dari berbagai kategori sekolah di Indonesia saat mengikuti pendidikan profesi guru (PPG) PAK menunjukkan bahwa sebagian guru menerapkan kurikulum pendidikan agama secara pleksibel, mereka juga mengaitkan materi ajar dengan kondisi kekinian masyarakat. Sebagian lain mengikuti materi dan kurikulum secara kaku atau menerapkan apa adanya, tidak melakukan modifikasi materi karena dipandang merupakan sistem yang diikuti tanpa harus mengubah materinya. Beberapa guru PAK yang secara fleksibel menerapkan kurikulum dan melakukan pengembangan materi ajar menyesuaikan dengan konteks masyarakat kontemporer Indonesia bertutur sebagai berikut:

Saya di sekolah, dalam hal memberi pelajaran agama memberi penekanan pada konteks dan perkembangan masyarakat kita. Jadi saya tetap mengikuti kurikulum yang berlaku tetapi penyajian materinya, saya selalu mengaitkan dengan peristiwa-peristiw yang sedang dialami masyarakat (MT, 40 th, guru PAK dari Jawa Tengah).

Dalam pembelajaran PAK di sekolah, sudah ada materi yang terkaiat kehidupan dalam keragaman. Saya biasa juga melakukan pengembangan materi dengan cara menemukan nilai dari setiap teks Alkitab yang diajarkan kepada siswa. Disini saya berusaha mengkaitkan teks dengan konteks masyarakat (YS, 37 th, guru PAK dari NTT)

Materi pembelajaran agama Kristen di sekolah sebetulnya sudah mengakomodir isu keragaman dan lingkungan, jadi memudahkan kami guru PAK untuk mengajari anak relasi dengan sesama maupun dengan lingkungan. Walau demikian bahasan materinya terbatas sehingga kami perlu menambah dengan memberi contoh kasus tertentu. Disini kami lalu mengaitkan dengan persitiwa hangat dalam masyarakat untuk memberi arah bagaimana sebaiknya anak bersikap (TR, 47 th, Guru PAK di Kota Ambon).

Kalau dilihat, materi-materi ajar PAK dari SD samapai SMA sudah implisit ajaran tentang pluralitas dan penghargaan terhadap sesama, tetapi memang masih kurang. Oleh karena itu diperlukan muatan materi tentang pendidikan agama multikultur, tapi ini khan perlu kebijakan lae (lagi), katong (kami) para guru hanya mengikuti saja (SW, 47 th, guru PAK Kabupaten SBB).

Cuplikan kutipan beberapa hasil percakapan dengan para guru sebagaimana dikemukakan menunjukkan bahwa sekalipun para guru PAK telah berinisiatif mengembangkan pembelajaran agama untuk membangun sikap inklusif siswa tetapi hal ini patut mendapat perhatian para pengambil kebijakan terkait dengan penyesuaian kurikulum dan bahan ajar memadai bagi para guru agama. Hal ini dipandang penting agar implementasi pendidikan agama dapat terjadi secara menyeluruh dan merata pada setiap daerah di Indonesia.

Disadari atau tidak kebijakan pendidikan agama di Indonesia belum mengalami perubahan siknifikan sejak masa Orde Baru hingga kini. Penelitian Suhadi, dkk. dari CRCS-UGM (2014) tentang politik pendidikan agama menegaskan bahwa sejak masa pemerintahan Orde Baru, pendidikan Agama ditetapkan menjadi mata pelajaran wajib di sekolah dasar hingga perguruan tinggi, dengan tujuan agar pendidikan agama yang diberi kepada setiap warga Indonesia dapat 
memproteksi paham komunisme. ${ }^{14}$ Pada masa reformasi hingga kini, gagasan serupa mengalami modifikasi yang melihat tugas dunia pendidikan secara umum dan khususnya posisi pendidikan agama adalah untuk "memperkuat keyakinan beragama". Temuan Suhadi dan kawan-kawan sebagaimana dikemukakan, menunjukkan orientasi pendidikan agama yang tetap eksklusif. Pendidikan agama, termasuk PAK, saat ini sudah sepatutnya diorientasikan pada tujuan membangun sikap beragama yang inklusif, yaitu penguatan pemahaman dan sikap beragama yang menghargai kemajemukan dan mampu membangun hidup harmoni dalam keragaman.

\section{Strategi Pengembangan Pendidikan Agama di Indonesia}

Sebagaimana disebut sebelumnya, pendidikan agama telah dijadikan mata pelajaran utama di Indonesia mulai dari Sekolah Dasar (SD) hingga Perguruan Tinggi (PT), tetapi sikap beragama di Indonesia menunjukkan bahwa penghargaan terhadap sesama umat beragama jauh dari apa yang diharapkan. Terhadap hal ini, studi ini menemukan bahwa terdapat beberapa persolaan substansi yang masih perlu dibenahi, seperti: kurikulum pendidikan agama, materi ajar pendidikan agama, dan jumlah jam pembelajaran agama yang terasa kurang.

Pertama, terkait eksistensi kurikulum pendidikan agama di Indonesia, diharapkan dapat membangun kesadaran kritis terhadap realitas kemajemukan. Oleh karena itu, patut berorientasi pada pengetahuan, sikap dan perilaku terbuka dan menerima perbedaan sebagai suatu fakta sosial dan keniscayaan yang tidak dapat diabaikan. Kedua, dalam kaitan dengan perubahan kurikulum maka materi ajar selaku pegangan guru dan siswa pun patut dikonstruksi menjawab tuntutan pembelajaran agama yang inklusif. Oleh karena pendidikan agama tidak hanya menekankan aspek pengetahuan semata tetapi juga perubahan sikap, perilaku dan kreatifitas siswa dalam berelasi dengan Sang Pencipta, berelasi dengan sesama yang beragam, berelasi dengan alam maka durasi waktu pembelajaran agama pun patut mendapat perhatian. Pendidikan agama sudah sepatutnya memiliki posisi penting dan sama dengan pembelajaran sains lain yang memerlukan waktu praktik dan atau pendalaman sehingga memerlukan waktu atau jam pembelajaran yang lebih banyak.

\section{Pendidikan Agama Inklusif: Merawat Keragaman dan Fondasi Moderasi Beragama}

Pendidikan agama inklusif di sini dapat dipahami sebagai bagian dari pendidikan untuk membangun penyadaran terhadap perbedaan sehingga menjadi bagian dari upaya mengelola keragaman dan upaya bina damai dalam arti luas. Dalam perspektif seperti dikemukakan maka, pendidikan agama inklusif merupakan proses transformasi pendidikan agama dari yang berorientasi pada penguatan doktrin dan keyakinan agama sendiri ke penguatan karakter dan penerimaan terhadap keanekaragaman, tanpa mengabaikan keyakinan agama masing-masing.

Pendidikan agama yang inklusif sesungguhnya dapat menjadi media dalam mengelola keberagaman karena pendidikan agama inklusif memiliki tujuan mengubah paradigma pendidikan yang melihat diri sendiri ke melihat diri dalam keberadaannya dengan orang lain. Selain itu, strategi pembelajaran agama inklusif mengutamakan penghargaan dan penggelolaan keragaman. ${ }^{15}$ Pendidikan agama yang inklusif sudah tentu membentuk pemahaman dan sikap moderat siswa dan berdampak kepada masyarakat secara luas.

Moderat merupakan sikap tengah tengah dan mampu menyesuaikan diri dengan kemajuan serta hakikat yang menjadi fondasi utamanya. Apabila hal ini dikaitkan dengan agama maka beragama yang moderat menunjuk pada sikap tidak cenderung ke kanan atau ke kiri secara ekstrim. Hakikatnya, agama-agama memiliki pengajaran tentang kedamaian dan kebaikan, tetapi dalam praktik terdapat pemahaman dan praktik keagamaan berbeda. Ada pemahaman dan

${ }^{14}$ Suhadi, Politik Pendidikan Agama: Kurikulum 2013 Di Ruang Publik Sekolah (Yogyakarta: CRCS UGM., 2014).

${ }^{15}$ Rumahuru, "Mengembangkan Pendidikan Agama Inklusif Sebagai Solusi Pengelolaan Keragaman Di Indonesia." 
praktik beragama yang sangat ekslusif dan sempit pemahaman tekstualnya. Ada pula pemahaman dan praktik beragama yang "kebablasan bebas" sehingga tidak menghiraukan kaidah-kaidah utama dalam ajarannya. Di sini sikap moderat merupakan pilihan yang lebih baik dalam praktik hidup beragama dan bermasyarakat yang majemuk.

Secara makro, kehadiran agama-agama dalam berbagai tradisi keagamaannya diakui menawarkan kedamaian, cinta kasih dan norma-norma hidup yang saling menghargai, dan menghidupkan tetapi kesalahan dalam interpretasi pengajaran (doktrin/aqidah) yang disampaikan kepada nara didik dapat membentuk pemahaman dan memproduksi kekerasan. ${ }^{16}$ Dalam kaitan ini diperlukan implementasi pendidikan agama yang inklusif.

Pendidikan agama, jika dipahami dalam perpektif teori kritis seperti disebut sebelum, maka dapat diposisikan sebagai kritik ideologi yang memiliki kekuatan aktif dan potensial untuk melakukan kritik sosial dan membangun pandangan kritis terhadap dunia, bukan sebagai pemelihara status qou. Dengan memosisikan pendidikan agama sebagai idiologi kritik (dalam bahasa Freire), pendidikan agama dan keagamaan di Indonesia memiliki kekuatan mendefinisikan kembali, memroduksi, dan mengubah habitus pendidikan agama konfensional yang eksklusif ke arah inklusif dan transformatif. Pendiidkan yang membentuk sikap inklusif dan transformatif sangat diperlukan dalam masyarakat multi etnik dan agama seperti Indonesia. ${ }^{17}$ Pendidikan agama yang inklusif sangat diperlukan untuk membangun sikap moderat nara didik, suatu sikap yang sangat penting dimiliki di tengah menguatnya radikalisme dan ekstrimisme agama di Indonesia akhirakhir ini.

\section{Dasar Teologi Kristen tentang PAK Inklusif}

Acuan membicarakan PAK inklusif sesungguhnya dapat ditelusuri dari konteks narasi Alkitab. Sebagai contah, dalam Alkitab Perjanjian Lama ditemui bahwa konteks masyarakat Israel sesungguhnya menggambarkan konteks yang plural baik dari sisi budaya maupun agama atau kepercayaan. Israel adalah suatu bangsa yang memang memiliki budaya dan agama sendiri namun kehidupan Israel bersentuhan dengan bangsa-bangsa lain yang berbeda budaya dan kepercayaan secara langsung maupun tidak langsung telah turut memberi dampak tersendiri bagi perkembangan budaya dan agama Israel. Bahkan, tidak dapat dipungkiri bahwa konteks masyaakat Israel yang tergambar di dalam Alkitab adalah bukti bahwa budaya dan agama bangsa lain telah turut mewarnai penulisan Alkitab Perjanjian Lama. Dalam perjumpaan dengan budaya dan agama bangsa lain, Israel turut mengadopsi, walau kemudian merumuskannya dalam bentuk lain karena adanya konsep teologis tertentu yang ingin dibangun Israel, yang membedakan Israel dari bangsa lain.

Patut disadari pula bahwa penekanan Perjanjian Lama pada masyarakat Israel sabagai umat yang dipanggil khusus oleh Allah dan diberkati, dikasihi serta diselamatkan oleh Allah tidak dapat dimaknai secara sempit bahwa berkat hanya diberi kepada Israel. Allah Yahweh yang disembah Israel memang menjanjikan berkat, kasih dan keselamatan kepada Israel lewat janjNya kepada Abraham bahwa Israel akan diberkati dan menjadi bangsa yang besar namun Israel juga diharapkan bisa menjadi berkat bagi bangsa-bangsa lain. Nabi Yesaya menyaksikan hal itu di dalam Yesaya 19:24-25 bahwa berkat, kasih dan keselamatan Allah juga tersedia bagi Mesir dan Asyur. Mesir disebutkan sebagai 'umatKu' Asyur disebut sebagai 'buatan tanganKu' dan Israel sebagai milik pusakaKu'. Predikat yang diberikan kepada ketiga bangsa ini kelihatannya berbeda namun demikian terdapat pengakuan terhadap Mesir dan Asyur yang juga mendapatkan berkat, kasih dan keselamatan dari Allah selain Israel. Nabi Yesaya pun menyaksikan bahwa Koresy, Raja Persia adalah orang yang dipakai untuk menaklukkan bangsa-bangsa lain dan kemenangan itu turut memberi dampak keselamatan bagi Israel. Bahkan, kemudian lewat Kores, Allah mengembalikan Israel ke tanah asalnya.

\footnotetext{
16 Ahnaf, Praktik Pengelolaan Keragaman Di Indonesia: Jalan-Jalan Alternatif Membangun Inklusi Sosial.

${ }^{17}$ M. Amin Abdulla, Pendidikan Agama Era Multikultural-Multireligius (Yogyakarta: PSAP, 2005).
} 
Narasi lain dalam Perjanjian Lama seperti Yunus 1:1-17 memberikan penekanan yang lebih kuat lagi terhadap keberagaman dan kesetaraan bangsan lain dengan Israel. Kisah Yunus pada bagian ini menegaskan tentang sebuah bentuk pengakuan terhadap realitas bangsa lain, yang memiliki budaya dan agama berbeda dengan Israel namun diakui sebagai manusia ciptaan Allah yang tetap layak mendapatkan keselamatan dari Allah. Pernyataan Yunus ini menjadi kritikan keras bahwa Allah sangat berpihak kepada semua manusia yang adalah ciptaanNya. Allah digambarkan sebagai Allah yang universal yang menerima kepelbagaian manusia.

Beberapa narasi dalam Alkitab Perjanjian Lama sebagaimana dikemukakan kiranya menjadi bukti bahwa pengakuan terhadap bangsa lain yang memiliki budaya dan agama berbeda menjadi hal penting yang dicontohkan dalam konteks Israel Perjanjian Lama. Apa bila komunitas Kristen semakin menyadari konteks Israel Perjanjian Lama seperti diuraikan sebelum maka tidak ada alasan pembelajaran PAK dijadikan doktrin sempit dan eksklusif. Menjadi tanggung jawab bersama pebelajar PAK adalah membangun perspektif teologi Kristen inklusif, mengacu pada teks Alkitab maupun kemajemukan masyarakat di Indonesia sebagai suatu teks yang penuh dinamika.

\section{KESIMPULAN}

Pendikan agama yang berorientasi pada penguatan doktrin agama sendiri yang tidak dibarengi dengan pengetahuan terhadap keberadaan agama atau kelompok di luar dirinya telah turut memengaruhi sikap eksklusif dan fanatisme sempit, dan berpotensi memroduksi individu atau kelompok orang yang radikal dan ekstrem dalam hal beragama. Terkait dengan hal tersebut diperlukan perubahan paradigma pendidikan agama yang memungkinkan setiap orang mengalami perjumpaan dan pembauran dengan kelompok lain. Studi ini merekomendasi pentingnya paradigma pendidikan agama inklusif sebagai salah satu solusi membangun pemikiran dan sikap moderasi beragama di Indonesia. Pendidikan agama inklusif dipandang strategis karena selain memungkinkan penerimaan satu terhadap lainnya juga dapat dijadikan instrumen pengelolaan keragaman jangka panjang. Hal ini karena pendidikan agama inklusif memungkinkan adanya sikap saling percaya dan penghargaan terhadap kesederajatan umat manusia yang memungkinkan pengakuan terhadap hak-hak setiap individu atau kelompok dalam masyarakat.

Dari perspektif teologi Kristen, ajaran Kristen "yang paling tua" dalam Alkitab Perjanjian Lama sekalipun, telah mengakui eksistensi bangsa lain dengan budaya dan agama atau kepercayaan mereka. Diakui bahwa Allah Yahweh yang disembah Israel, menyediakan berkat, kasih dan keselamatan juga kepada bangsa-bangsa lain, sama seperti yang diberi kepada Israel. Perspektif teologi ini menjadi dasar bagi pengembangan PAK inklusif.

\section{REFERENSI}

Abdulla, M. Amin. Pendidikan Agama Era Multikultural-Multireligius. Yogyakarta: PSAP, 2005.

Ahnaf, Iqbal M. Praktik Pengelolaan Keragaman Di Indonesia: Jalan-Jalan Alternatif Membangun Inklusi Sosial. Yogyakarta: CRCS UGM, 2018.

Ali-Fauzi, Ihsan. Buku Panduan Melawan Hasutan Kebencian. Jakarta: PUSAD Yayasan Paramadina, 2019.

Banks, James A. "Approaches to Multicultural Curriculum Reform." In Multicultural Education: Issues and Perspectives, edited by James A Banks and Cherry A.McGee Banks. New York: Jhon Willey \& Sons.Inc, 2010.

Baqir, Z A. Mengelola Keragaman Dan Kebebasan Beragama Di Indonesia: Sejarah, Teori Dan Advokasi. Yogyakarta: Sekolah Pascasarjana UGM CRCS, 2014.

Dodi, Nandika. Pendidikan Di Tengah Gelombang Perubahan. Jakarta: LP3ES, 2007.

Freire, Paulo. Politics and Education. California \: UCLA Latin American Center Publications, 1998.

Freire, Paulo, and Anna Maria Araujo. Pedagogy of Hope: Reliving Pedagogy of the Oppressed. New York: Continuum, 1994. 
Listia, Laode Arham, and Lian Gogali. "Problematika Pendidikan Agama Di Sekolah: Hasil Penelitian Tentang Pendidikan Agama Di Kota Jogjakarta 2004-2006." Yogyakarta: Interfidei/Dian (2007).

Mudyahardjo. Filsafat Pendidikan. Bandung: Remaja Rosda Karya, 2002.

Rumahuru, Y Z. "Keragaman Agama Sebagai Basis Pembelajaran PAK." MARA CHRISTY 5, no. 2 (2014).

"Mengembangkan Dialog Untuk Penguatan Misi Agama Yang Transformatif." KENOSIS: Jurnal Kajian Teologi 2, no. 1 (2016): 23-35.

Rumahuru, Yance Z. "Mengembangkan Pendidikan Agama Inklusif Sebagai Solusi Pengelolaan Keragaman Di Indonesia." Jurnal Teruna Bhakti 1, no. 1 (2019): 59-68.

Saerozi, M. Politik Pendidikan Agama Dalam Era Pluralisme. Yogyakarta: Tiara Wacana, 2004.

Soebaedi. Pendidikan Berbasis Masyarakat: Upaya Menawarkan Solusi Terhadap Berbagai Problem Sosial. Ygyakarta: Puataka Pelajar, 2006.

Suhadi. Politik Pendidikan Agama: Kurikulum 2013 Di Ruang Publik Sekolah. Yogyakarta: CRCS UGM., 2014. 